\title{
Nutritional Qualities of Ready to Reconstitute Carrot Flavoured Milk Beverage
}

\author{
N. Karthikeyan*, P. Karthi and G. Kumaresan \\ Department of Livestock Products Technology-Dairy Science, Veterinary College and \\ Research Institute, Namakkal, TamilNadu, India \\ *Corresponding author
}

\section{Keywords}

Carrot flavoured milk, Gross energy, Fat, Moisture, Nutritional parameters, Protein, Ready-toreconstitute milk beverage, Spray drying

\section{Article Info}

Accepted:

04 September 2020 Available Online: 10 October 2020

\section{A B S T R A C T}

Production of dried milk powders by using a novel technique of spray drying is to enhance the storage life of milk, making it convenient to reconstitute without much loss of nutrients. A study was conducted to develop a ready to reconstitute milk beverage by using the spray drying technology with optimum nutritional parameters. Ready to reconstitute milk beverage was prepared by incorporation of 20 per cent level of carrot extract and 1.5 per cent level of cardamom with varying levels of milk fat3, 4.5, 1.5 and 0.5 per cent as Control, T1, T2 and T3. Further, the selected treatments and control were subjected to spray drying technology with standardized spray drying parameters and packed in polyethylene bags and stored at room temperature for 120 days during which the nutritional parameters were studied on day $0,30,60,90$ and 120 . The protein content was found highest for T3, 35.52 per cent and lowest for the control 30.03 per cent, similarly the ash content was found highest for T3, 8.11 per cent than control and other treatments, while the fat content was highest for T1, 26.67 per cent and lowest for T3, 1.21 per cent, further the lowest moisture content of 4.09 per cent was observed for control and highest for T3, 4.10 per cent, Further the lowest energy value of $428.59 \mathrm{kcal} / 100 \mathrm{gm}$ was observed for T3 and highest for T1, $507.13 \mathrm{kcal} / 100 \mathrm{gm}$ on day 120 of storage. It was concluded that ready to reconstitute milk beverage can be prepared by using skim milk ( 0.5 per cent milk fat), carrot extract 20 per cent and cardamom 1.5 per cent with standardized parameters of spray drying technology as input feed rate at 8RPM, inlet temperature at $185.0^{\circ} \mathrm{C}$ for set 1 and $195.0^{\circ} \mathrm{C}$ for set2, outlet temperature at $102.5^{\circ} \mathrm{C}$ for set 1 and $105.5^{\circ} \mathrm{C}$ for set 2 and with better nutritional qualities.

\section{Introduction}

Ready to serve foods are those that are consumed immediately without much cooking/working like milk powder. Today there is a demand for ready-to-serve convenience food among consumers. Fruit or vegetable beverages such as ready to serve are becoming increasingly popular in comparison to synthetic drinks, because of their taste, flavour and nutritive value.

Spray drying is the most suitable technique for producing milk powders and the removal of water which prevents the growth of microorganisms by reducing the water 
activity and facilitates preservation and storage of milk constituents ${ }^{[15]}$. It was also used to encapsulate carotene from carrot ${ }^{[5]}$.

Carrot is an important root vegetable rich in carotenoids $^{[16]}$, vitamin $\mathrm{C}$, calcium, iron and magnesium $^{[14]}$. Carrot root has plenty of antioxidant activity and contain $80 \%$ of linoleic acid $^{[3]}$

Cardamom acts as flavouring agent in food products with a lot of health properties like antioxidant, blood pressure lowering, fibrinolysis enhancing, diuretic and sedative $^{[6]}$.

Nowadays, consumer demand is increasing for low fat foods made with value added ingredients such as carotenoids.

Hence the present study has been carried out to enhance the properties of ready to reconstitute milk beverage by using carrot extract and cardamom with increased shelf life by spray drying technology.

\section{Materials and Methods}

\section{Cow milk}

High quality fresh milk was obtained from crossbred cows at the Livestock Farm Complex, Veterinary College and Research Institute, Namakkal, Tamil Nadu.

\section{Carrot juice and Cardamom}

Good quality fresh carrots and cardamom were purchased from the local market which are utilized for this study.

\section{Skim milk powder and Butter}

Good quality Skim milk powder and Butter was obtained from the District Cooperative Milk Producers Union Limited (Aavin), Salem, Tamil Nadu, India was utilized for this study.

\section{Experimental design}

The following three combinations of treatment and control have been prepared for this study.

\begin{tabular}{|c|c|c|c|}
\hline \multirow{2}{*}{$\begin{array}{l}\text { Selected } \\
\text { treatments }\end{array}$} & \multirow{2}{*}{$\begin{array}{c}\text { Fat contentin milk } \\
\qquad(\%)\end{array}$} & \multicolumn{2}{|c|}{ Levels of ingredients } \\
\hline & & Carrot extract (\%) & Cardamom (\%) \\
\hline Control & 3.0 & 20 & 1.5 \\
\hline$T_{1}$ & 4.5 & 20 & 1.5 \\
\hline $\mathbf{T}_{2}$ & 1.5 & 20 & 1.5 \\
\hline $\mathbf{T}_{3}$ & 0.5 & 20 & 1.5 \\
\hline Inlet Temperature & \multicolumn{2}{|c|}{ Outlet Temperature } & De-block nozzle \\
\hline \multirow{2}{*}{$\begin{array}{l}\text { Set } 1-185.5^{\circ} \mathrm{C} \\
\text { Set } 2-195.5^{\circ} \mathrm{C}\end{array}$} & \multicolumn{2}{|c|}{ Set $1-102.5^{\circ} \mathrm{C}$} & On-1second \\
\hline & \multicolumn{2}{|c|}{ Set $2-105.5^{\circ} \mathrm{C}$} & Off-60 seconds \\
\hline
\end{tabular}

The prepared/spray dried ready to reconstitute milk beverage powder was collected in a polyethylene cover and stored in a cool and dry place at ambient temperature.

\section{Nutritional parameters}

Moisture: As per $\mathrm{AOAC}^{[2]}, 5 \mathrm{~g}$ of sample was taken in a dry petri dish and placed in an oven at $105^{\circ} \mathrm{C}$ for overnight. The samples were desiccated and weighed. The dish was returned into the oven for another half hour and again cooled and reweighed. The process was repeated until a constant weight was reached.

Moisture $\%=\underline{\text { Fresh weight of sample }- \text { Dry weight of sample }} \times 100$ Fresh weight of sample 
Fat: $5 \mathrm{~g}$ of sample was taken and the fat content was determined by Soxhlet extraction $\operatorname{method}^{[13]}$.

Protein: $2 \mathrm{~g}$ of sample was taken and protein was estimated by Kjeldahl nitrogen $\operatorname{method}^{[13]}$.

Ash: $5 \mathrm{~g}$ of sample was weighed into porcelain crucible previously ignited and weighed. The material was ignited in the fume cupboard until no fumes was seen charred of the organic matter and then transferred into a muffle furnace at $550^{\circ} \mathrm{C}$ for $3 \mathrm{hr}$., and cooled in a desiccator and weighed $^{[7]}$.

Total ash \% $=($ Weight of ash + Crucible weight $)-$ Empty weight of crucible $\times 100$

Weight of sample

Gross energy: Gross energy was calculated from other proximate parameters ${ }^{[7]}$.

Statistical analysis: The data were analyzed by two-way ANOVA in SPSS (version 20.0).

\section{Results and Discussion}

Moisture content: It was observed that there was no significant difference noticed between treatments and also between different treatments on a particular day of storage (Table 1). The lowest moisture content was $4.00 \pm 0.03$ for control on day 90 of storage and the highest was observed for T3 (4.10 \pm 0.03 ) on day 120 of storage. The result revealed that there were no significant changes in moisture content and it may be due to efficient temperature of processing, packaging and also no chances of absorption of moisture by lactose content of the developed powder. According to FSSAI, the maximum moisture content of all kinds of milk powder should be 5 per cent. The result of the present study is in accordance with the reports of Cristina et al., (2012) ${ }^{[4]}$ where moisture content of infant formula was maintained until the $6^{\text {th }}$ month of storage. These results agreed with the results obtained by Kim et al., (2009) ${ }^{[11]}$, who reported that the moisture content of skim milk powder was 3.5 per cent and whole milk powder was 3 per cent further Kumar and Murthy (1992) [12] found the average moisture of buffalo whole milk powder was 3.23 per cent.

Fat content: The results (Table 2) showed that the fat content ranged from $1.20 \pm 0.01$ to $26.67 \pm 0.02$ and a significant difference was noticed between treatments on particular periods of storage but no significant difference was observed within a treatment during storage period. The highest fat per cent $(16.78 \pm 0.19)$ was observed on the day 60 of storage for control and the lowest fat content was observed for T3 $(1.20 \pm 0.01)$ on day 90 of storage. Fat content of different treatments and control of ready to reconstitute milk beverage highly varied because of initial fat content of milk from which it was produced but in any treatment fat content had not changed during different storage periods and reflected that there were no chemical and microbial changes occurred during storage period. The result of this study showed that fat content of all treatments was within the prescribed standards as per FSSAI $(2011)^{[8]}$. The result correlates with the study conducted by Kim et al., (2009) ${ }^{[11]}$ who reported that the skim milk powder contained 1.0 per cent fat and whole milk powder contained 26.6 per cent fat and Kumar and Murthy (1992) ${ }^{[12]}$ found the fat content of buffalo whole milk powder was 26.1 per cent. 
Table.1 Moisture content (\%) of ready to reconstitute milk beverage during storage

\begin{tabular}{|c|c|c|c|c|c|}
\hline \multirow{2}{*}{ Treatment } & \multicolumn{5}{|c|}{ Storage period (in days) } \\
\cline { 2 - 6 } & $\mathbf{0}$ & $\mathbf{3 0}$ & $\mathbf{6 0}$ & $\mathbf{9 0}$ & $\mathbf{1 2 0}$ \\
\hline Control & $4.09 \pm 0.03$ & $4.08 \pm 0.04$ & $4.06 \pm 0.03$ & $4.00 \pm 0.03$ & $4.09 \pm 0.03$ \\
\hline $\mathbf{T}_{\mathbf{1}}$ & $4.07 \pm 0.01$ & $4.05 \pm 0.02$ & $4.06 \pm 0.02$ & $4.03 \pm 0.03$ & $4.05 \pm 0.03$ \\
\hline $\mathbf{T}_{\mathbf{2}}$ & $4.01 \pm 0.02$ & $4.04 \pm 0.02$ & $4.02 \pm 0.01$ & $4.04 \pm 0.02$ & $4.03 \pm 0.04$ \\
\hline $\mathbf{T}_{\mathbf{3}}$ & $4.08 \pm 0.04$ & $4.01 \pm 0.02$ & $4.04 \pm 0.02$ & $4.06 \pm 0.04$ & $4.10 \pm 0.03$ \\
\hline
\end{tabular}

Table.2 Fat content (\%) of ready to reconstitute milk beverage during storage

\begin{tabular}{|c|c|c|c|c|c|}
\hline \multirow{2}{*}{ Treatment } & \multicolumn{5}{|c|}{ Storage period (in days) } \\
\cline { 2 - 6 } & $\mathbf{0}$ & $\mathbf{3 0}$ & $\mathbf{6 0}$ & $\mathbf{9 0}$ & $\mathbf{1 2 0}$ \\
\hline Control & $16.75^{\mathrm{c}} \pm 0.22$ & $16.75^{\mathrm{c}} \pm 0.25$ & $16.78^{\mathrm{c}} \pm 0.19$ & $16.70^{\mathrm{c}} \pm 0.19$ & $16.67^{\mathrm{c}} \pm 0.13$ \\
\hline $\mathbf{T}_{\mathbf{1}}$ & $26.67^{\mathrm{d}} \pm 0.02$ & $26.62^{\mathrm{d}} \pm 0.03$ & $26.60^{\mathrm{d}} \pm 0.04$ & $26.57^{\mathrm{d}} \pm 0.03$ & $26.55^{\mathrm{d}} \pm 0.02$ \\
\hline $\mathbf{T}_{\mathbf{2}}$ & $8.75^{\mathrm{b}} \pm 0.13$ & $8.75^{\mathrm{b}} \pm 0.29$ & $8.65^{\mathrm{b}} \pm 0.14$ & $8.67^{\mathrm{b}} \pm 0.16$ & $8.60^{\mathrm{b}} \pm 0.13$ \\
\hline $\mathbf{T}_{\mathbf{3}}$ & $1.22^{\mathrm{a}} \pm 0.01$ & $1.23^{\mathrm{a}} \pm 0.02$ & $1.21^{\mathrm{a}} \pm 0.02$ & $1.20^{\mathrm{a}} \pm 0.01$ & $1.21^{\mathrm{a}} \pm 0.01$ \\
\hline
\end{tabular}

Mean \pm (SE) bearing different superscripts in same column differ significantly $(\mathrm{P}<0.05)$

Table.3 Protein content (\%) of ready to reconstitute milk beverage during storage

\begin{tabular}{|c|c|c|c|c|c|}
\hline \multirow{2}{*}{ Treatment } & \multicolumn{5}{|c|}{ Storage period (in days) } \\
\cline { 2 - 6 } & $\mathbf{0}$ & $\mathbf{3 0}$ & $\mathbf{6 0}^{\mathrm{b}}$ & $\mathbf{9 0}$ & $\mathbf{1 2 0}$ \\
\hline Control & $29.92^{\mathrm{b}} \pm 0.15$ & $29.97^{\mathrm{b}} \pm 0.14$ & $29.90^{\mathrm{b}} \pm 0.13$ & $30.07^{\mathrm{b}} \pm 0.12$ & $30.03^{\mathrm{b}} \pm 0.12$ \\
\hline $\mathbf{T}_{\mathbf{1}}$ & $26.55^{\mathrm{a}} \pm 0.02$ & $26.57^{\mathrm{a}} \pm 0.01$ & $26.57^{\mathrm{a}} \pm 0.03$ & $26.58^{\mathrm{a}} \pm 0.01$ & $26.58^{\mathrm{a}} \pm 0.02$ \\
\hline $\mathbf{T}_{\mathbf{2}}$ & $33.27^{\mathrm{c}} \pm 0.08$ & $33.00^{\mathrm{c}} \pm 0.11$ & $32.97^{\mathrm{c}} \pm 0.17$ & $32.98^{\mathrm{c}} \pm 0.08$ & $32.92^{\mathrm{c}} \pm 0.17$ \\
\hline $\mathbf{T}_{\mathbf{3}}$ & $35.48^{\mathrm{d}} \pm 0.15$ & $35.47^{\mathrm{d}} \pm 0.13$ & $35.50^{\mathrm{d}} \pm 0.13$ & $35.37^{\mathrm{d}} \pm 0.15$ & $35.52^{\mathrm{d}} \pm 0.15$ \\
\hline
\end{tabular}

Mean $\pm(\mathrm{SE})$ bearing different superscripts in same column differ significantly $(\mathrm{P}<0.05)$

Table.4 Ash content (\%) of ready to reconstitute milk beverage during storage

\begin{tabular}{|c|c|c|c|c|c|}
\hline \multirow{2}{*}{ Treatment } & \multicolumn{5}{|c|}{ Storage period (in days) } \\
\cline { 2 - 6 } & $\mathbf{0}$ & $\mathbf{3 0}$ & $\mathbf{6 0}$ & $\mathbf{9 0}$ & $\mathbf{1 2 0}$ \\
\hline Control & $6.17^{\mathrm{b}} \pm 0.03$ & $6.18^{\mathrm{b}} \pm 0.03$ & $6.22^{\mathrm{b}} \pm 0.03$ & $6.15^{\mathrm{b}} \pm 0.03$ & $6.20^{\mathrm{b}} \pm 0.03$ \\
\hline $\mathbf{T}_{\mathbf{1}}$ & $4.73^{\mathrm{a}} \pm 0.04$ & $4.73^{\mathrm{a}} \pm 0.03$ & $4.76^{\mathrm{a}} \pm 0.03$ & $4.76^{\mathrm{a}} \pm 0.03$ & $4.77^{\mathrm{a}} \pm 0.03$ \\
\hline $\mathbf{T}_{\mathbf{2}}$ & $6.58^{\mathrm{c}} \pm 0.03$ & $6.59^{\mathrm{c}} \pm 0.04$ & $6.60^{\mathrm{c}} \pm 0.04$ & $6.60^{\mathrm{c}} \pm 0.03$ & $6.62^{\mathrm{c}} \pm 0.03$ \\
\hline $\mathbf{T}_{\mathbf{3}}$ & $8.11^{\mathrm{d}} \pm 0.02$ & $8.10^{\mathrm{d}} \pm 0.02$ & $8.12^{\mathrm{d}} \pm 0.02$ & $8.11^{\mathrm{d}} \pm 0.02$ & $8.11^{\mathrm{d}} \pm 0.01$ \\
\hline
\end{tabular}

Mean $\pm(\mathrm{SE})$ bearing different superscripts in same column differ significantly $(\mathrm{P}<0.05)$

Table.5 Gross energy $(\mathrm{kcal} / 100 \mathrm{~g})$ of ready to reconstitute milk beverage during storage

\begin{tabular}{|c|c|c|c|c|c|}
\hline \multirow{2}{*}{ Treatment } & \multicolumn{5}{|c|}{ Storage period (in days) } \\
\cline { 2 - 6 } & $\mathbf{0}$ & $\mathbf{3 0}$ & $\mathbf{6 0}^{\circ}$ & $\mathbf{9 0}$ & $\mathbf{1 2 0}$ \\
\hline Control & $484.47^{\mathrm{c}} \pm 0.98$ & $482.44^{\mathrm{c}} \pm 0.98$ & $483.74^{\mathrm{c}} \pm 0.70$ & $483.90^{\mathrm{c}} \pm 0.79$ & $482.23^{\mathrm{c}} \pm 0.35$ \\
\hline $\mathbf{T}_{\mathbf{1}}$ & $508.56^{\mathrm{d}} \pm 0.66$ & $508.24^{\mathrm{d}} \pm 0.72$ & $507.73^{\mathrm{d}} \pm 0.48$ & $507.15^{\mathrm{d}} \pm 0.34$ & $507.13^{\mathrm{d}} \pm 0.26$ \\
\hline $\mathbf{T}_{\mathbf{2}}$ & $452.16^{\mathrm{b}} \pm 0.68$ & $450.92^{\mathrm{b}} \pm 0.63$ & $451.49^{\mathrm{b}} \pm 0.69$ & $450.56^{\mathrm{b}} \pm 0.79$ & $450.27^{\mathrm{b}} \pm 0.36$ \\
\hline $\mathbf{T}_{\mathbf{3}}$ & $429.44^{\mathrm{a}} \pm 0.43$ & $429.27^{\mathrm{a}} \pm 0.42$ & $429.10^{\mathrm{a}} \pm 0.49$ & $428.18^{\mathrm{a}} \pm 0.46$ & $428.59^{\mathrm{a}} \pm 0.20$ \\
\hline
\end{tabular}

Mean $\pm(\mathrm{SE})$ bearing different superscripts in same column differ significantly $(\mathrm{P}<0.05)$ 
Flow chart for the preparation of ready to reconstitute milk beverage

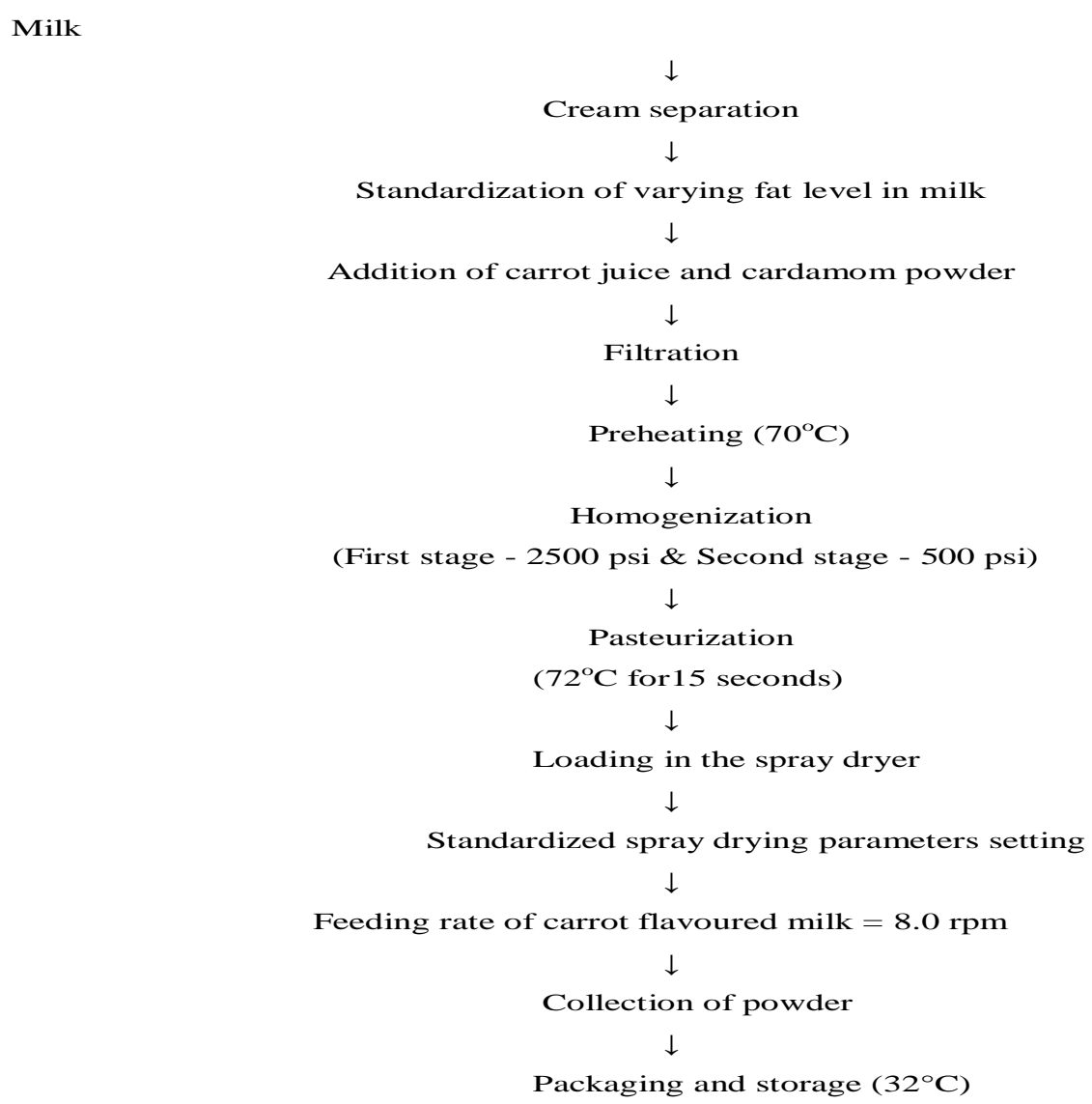

Protein content: The results showed that (table 3) the lowest and highest value of protein content was $26.55 \pm 0.02$ and $35.52 \pm$ 0.15 respectively. The mean $\pm \mathrm{SE}$ values of protein content of ready to reconstitute milk beverage showed a significant difference $(\mathrm{P}<0.05)$ between the different treatments and control. But during the storage period there were not many changes noticed in a particular treatment.

The variation in protein content between treatments was mainly due to initial protein content of milk in which the product was prepared and during storage there were no proteolytic changes noticed. These results of this study are within the FSSAI $(2011)^{[8]}$ standards with minimum 34 per cent of protein in milk powder. The results of this study are in accordance with the findings of
Simova and Ruzickova (1979) ${ }^{[17]}$ who reported that the average protein content of dried whole milk was 25.0 to 25.5 per cent. Further Kim et al., (2009) ${ }^{[11]}$ reported that the protein content of skim milk and whole milk powder was 36 and 27.9 per cent respectively.

Ash content: The mean \pm SE values for ash content of different treatments stored at different storage periods ranging from $4.73 \pm$ 0.03 to $8.12 \pm 0.02$ (table 4). Statistical analysis of ash content revealed a significant difference $(\mathrm{P}<0.05)$ between the different treatments and control in a particular day of storage and it may be due to the variation in the SNF and moisture content of the product.

The results obtained in this study are within the standards of FSSAI, $(2011)^{[8]}$ with maximum ash content of whole milk powder 
7.3 per cent and skim milk powder was 8.2 per cent. Kumar and Murthy (1992) ${ }^{[12]}$ reported that the ash content of buffalo whole milk powder was 5.67 per cent which was similar to the ash content of the product of this study. Further Amrita et al., (1998) ${ }^{[1]}$ found that the ash content of partly skimmed milk powder was 5.69 per cent. Kim et al., $(2009)^{[11]}$ found that the ash content of skim milk powder was 8.5 per cent and whole milk powder was 5.9 per cent and also Kajal et al., $(2012)^{[10]}$ reported that ash content of whole milk powder was $5.34-5.48 \mathrm{~g} / 100 \mathrm{~g}$.

Gross energy: The mean \pm SE values for gross energy content of different treatments stored at different storage period ranged from $428.18 \pm 0.46$ to $508.56 \pm 0.66$ (Table 5). The variation in gross energy content of treatments and control may be due to the variation in the fat, protein and lactose content of various treatments and control. No significant difference was observed within a treatment during different storage period this may be due to no lipolysis, proteolysis and microbiological changes during storage period.

The results are in accordance with the findings of Gopalan et al., $(1980)^{[9]}$ who reported that the energy value of whole milk powder was $496 \mathrm{kcal} / 100 \mathrm{~g}$ and skim milk powder was $357 \mathrm{kcal} / 100 \mathrm{~g}$ of powder.

In conclusion the present study, it was observed that ready to reconstitute milk beverage prepared by using skim milk (0.5 per cent milk fat), carrot extract 20 per cent and cardamom 1.5 per cent with standardized parameters for spray drying technology as input feed rate at 8RPM, inlet temperature on $185.0^{\circ} \mathrm{C}$ for set 1 and $195.0^{\circ} \mathrm{C}$ for set2,outlet temperature on $102.5^{\circ} \mathrm{C}$ for set 1 and $105.5^{\circ}$ $\mathrm{C}$ for set 2 showed a good nutritional and shelf life qualities of up to 120 days at room temperature.

\section{References}

1. Amrita K, Srivastava DN, Dabur RS and Kadian A (1998). Bacteriological and sensory qualities of milk powders manufactured in Haryana Agricultural University. Journal of Research. 28(4): 129-134.

2. AOAC (2005). Association of Agricultural Chemists; Official method of analysis, $20^{\text {th }} \mathrm{Ed}$. Washington, DC.

3. ArabshahiDS, Devi DV and Urooj A (2007). Evaluation of antioxidant activity of some plant extracts and their heat, $\mathrm{pH}$ and storage stability. Food Chemistry.100(3): 1100-1105.

4. Cristina SA, Sevastiţa M, AncuţaRM, Ramona S and Maria T (2012). Influence of the storage conditions on physicochemical parameters of infant formula. Journal of Agroalimentary Processes Technologies. 18: 61-64.

5. Desobry SA, Netto FM and Labuza TP (1998). Preservation of $\beta$-carotene from carrots. Critical Reviews in Food Science and Nutrition. 38(5): 381-396.

6. Dhulap S, Anita M and Hirwani RR (2008). Phyto-pharmacology of Elettaria cardamom Review.2(4): 27-35.

7. Egbenni UPO, Okolie PN, Akintunde TI, Bisi-Johnson O, Enwe L and Bessong PO (2010). Proximate analysis and microbiological quality of cheese produced from raw cow milk obtained from Fulani settlement in Ogun state, Nigeria using lactic acid bacteria and extract from sodom apple leaf. Pakistan Journal of Nutrition 9: 920-925.

8. Food Safety and Standards Authority of India (FSSAI), 2011.

9. Gopalan C, Rama BV, Sastri and Balasubramanian SC. (1980). Nutrition value of Indian foods.

10. Kajal MFI, Wadud A, Islam MN and Sarma PK (2012). Evaluation of some chemical parameters of powder milk 
available in Mymensingh town. Journal of the Bangladesh Agricultural University. 10(1): 95-100.

11. Kim EHJ, Chen XD and Pearce D. (2009). Surface composition of industrial spray-dried milk powders. 2 . Effects of spray drying conditions on the surface composition. Journal of Food Engineering. 94(2): 169-181.

12. Kumar S and Murthy BN. (1992). Incidence of LP system on the nutritional quality of milk proteins. Indian Journal of Dairy Science. 42(2): 198-202.

13. Ogunlade OA, Olusegun OV and Okhonlaye OA. (2017). Percentage Yield and Proximate Composition of Cheese Produced from Sheep Milk Using Different Coagulants. International Journal of Microbiology
Biotechnology. 2: 171-175.

14. Olalude CB, Oyedeji FO and Adegboyega AM. (2015). Physicochemical analysis of daucuscarota (carrot) juice for possible industrial applications. Journal of Applied Chemistry. 8(8): 110-113.

15. Schuck P (2002). Spray drying of dairy products. State of the art/ Le Lait. 82(4): 375-382.

16. Sharma KD, Karki S, Thakur NS and Attri S (2012). Chemical composition, functional properties and processing of carrot - A review of Journal of Food Science Technology.49(1): 22-32.

17. Simova J and Ruzickova D. (1979). Effect of storage on nutritional value of proteins in dried whole milk. Dairy Science Abstract. 41(5): 308.

\section{How to cite this article:}

Karthikeyan, N., P. Karthi and Kumaresan, G. 2020. Nutritional Qualities of Ready to Reconstitute Carrot Flavoured Milk Beverage. Int.J.Curr.Microbiol.App.Sci. 9(10): 194-200. doi: https://doi.org/10.20546/ijcmas.2020.910.025 